\title{
Shear Strength Measuring Equipment Evaluation at the Cold Test Facility
}

\author{
J. E. Meacham \\ Washington River Protection Solutions, LLC \\ Richland, WA 99352 \\ U.S. Department of Energy Contract DE-AC27-08RV14800

$\begin{array}{llll}\text { EDT/ECN: } & \text { NA } & \text { UC: NA } & \\ \text { Cost Center: } & \text { 2KE00 } & \text { Charge Code: } & \text { NA } \\ \text { B\&R Code: } & \text { NA } & \text { Total Pages: } & 27\end{array}$

Key Words: Shear Strength, Cone Penetrometer, CPT, Double-Shell Tank, Nuclear Waste, In Situ Shear Strength Measurement, Cold Test Facility

Abstract: Retrievals under current criteria require that approximately 2,000,000 gallons of double-shell tank (DST) waste storage space not be used to prevent creating new tanks that might be susceptible to buoyant displacement gas release events (BDGRE). New criteria are being evaluated, based on actual sludge properties, to potentially show that sludge wastes do not exhibit the same BDGRE risk. Implementation of the new criteria requires measurement of in situ waste shear strength. Cone penetrometers were judged the best equipment for measuring in situ shear strength and an A.P. van den Berg Hyson $100 \mathrm{kN}$ Light Weight Cone Penetrometer (CPT) was selected for evaluation. The CPT was procured and then evaluated at the Hanford Site Cold Test Facility. Evaluation demonstrated that the equipment with minor modification was suitable for use in Tank Farms.

TRADEMARK DISCLAIMER. Reference herein to any specific commercial product, process, or service by trade name, trademark, manufacturer, or otherwise, does not necessarily constitute or imply its endorsement, recommendation, or favoring by the United States Government or any agency thereof or its contractors or subcontractors.
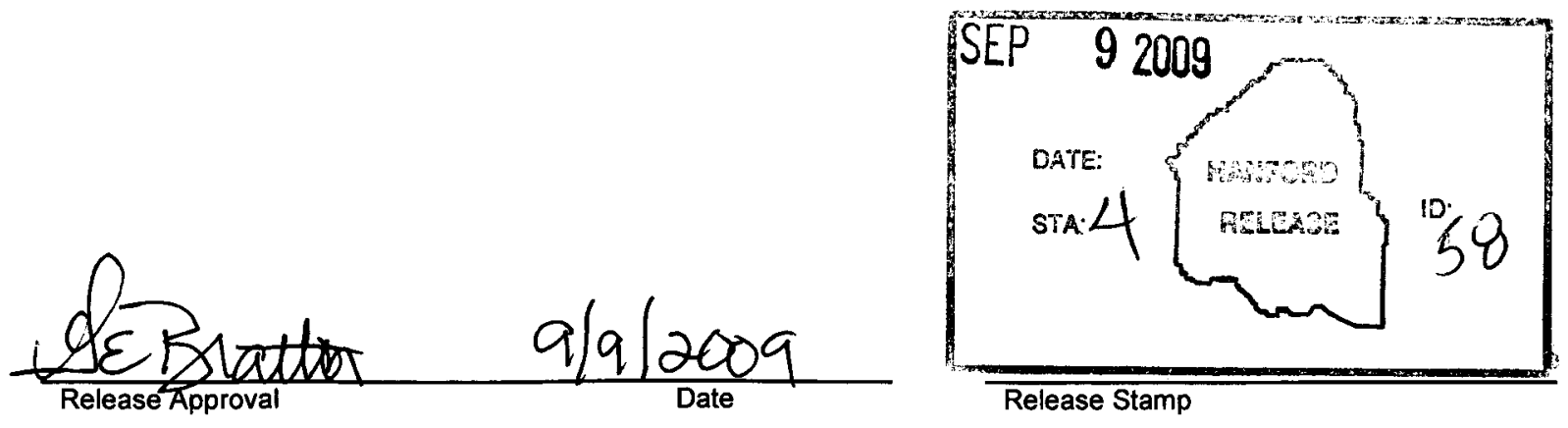

\section{Approved For Public Release}




\section{Shear Strength Measuring Equipment Evaluation at the Cold Test Facility}

\section{J.E. Meacham}

Washington River Protection Solutions, LLC

Date Published

Sepetmber 2009

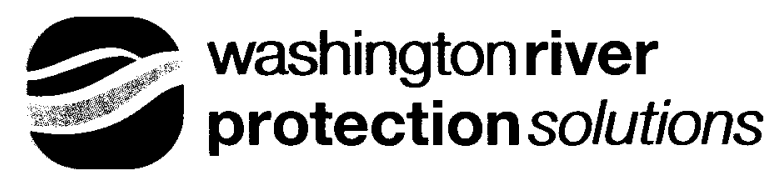

Prepared for the U.S. Department of Energy Office of River Protection

Contract No. DE-AC27-08RV14800 


\section{EXECUTIVE SUMMARY}

Retrievals under current criteria require that approximately 2,000,000 gallons of double-shell tank (DST) waste storage space not be used to prevent creating new tanks that might be susceptible to buoyant displacement gas release events (BDGRE). New criteria are being evaluated, based on actual sludge properties, to determine if sludge wastes exhibit the same BDGRE risk as salt cake wastes. If they do not, then this reserved DST waste storage space might be safely utilized. Implementation of the new criteria requires measurement of in situ waste shear strength.

A request of interest, literature search and vendor survey were conducted to find a DST waste in situ shear strength measurement tool. Cone penetrometers were judged the best equipment for measuring in situ shear strength and an A.P. van den Berg Hyson 100-kN Light Weight Cone Penetrometer was selected for evaluation. The cone penetrometer was procured and then evaluated at the Hanford Site Cold Test Facility (CTF). Evaluation at CTF demonstrated that the cone penetrometer was suitable for use in Tank Farms. The evaluation also identified recommended modifications before deployment in DSTs. Recommendations included small changes to the software, a modified hydraulic power pack and addition of a hydraulic catching clamp. A complete cone penetrometer system was procured and evaluated at CTF in less than six months and the estimated cost for a modified cone penetrometer is just under $\$ 70,000$. Evaluation was completed in less than half the time estimated in the expression of interest responses at about one-sixth the cost. 


\section{CONTENTS}

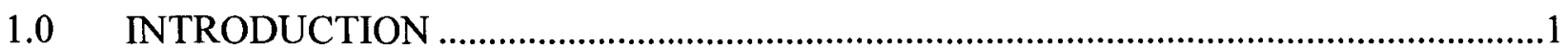

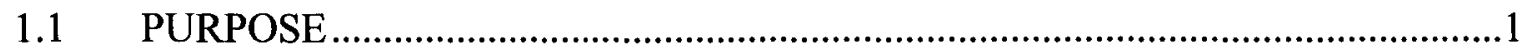

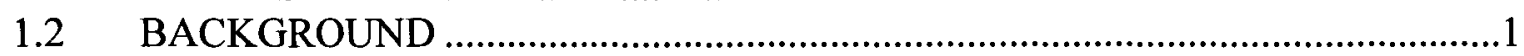

1.2.1 Current Criteria Based on DST Salt Slurry Behavior ....................................1

1.2.2 Proposed Criteria Based on Dutch Work.....................................................2

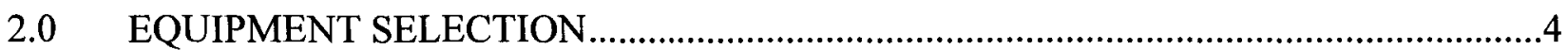

2.1 PERFORMANCE CRITERIA...................................................................4

2.2 REQUEST OF INTEREST ........................................................................

2.3 LITERATURE SEARCH \& VENDOR SURVEY ...............................................

2.3.1 Technologies Considered...........................................................................

2.3.2 Potential Cone Penetrometer Vendors ........................................................6

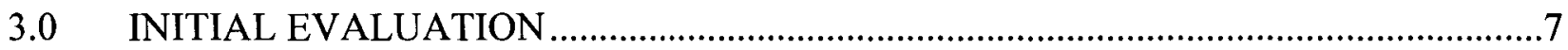

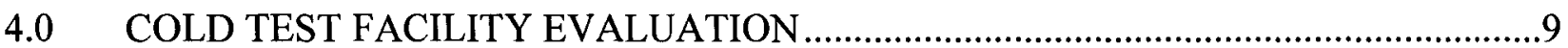

4.1 SOFTWARE AND ELECTRICAL COMPONENTS................................................

4.2 RISER MOUNT ASSEMBLY …...............................................................

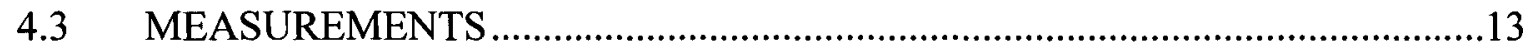

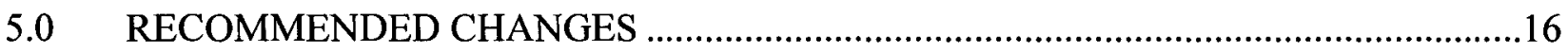

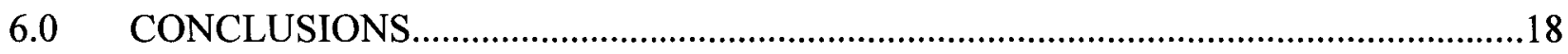

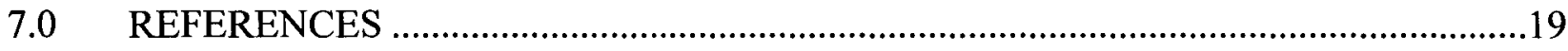




\section{FIGURES}

Figure 1. Hyson $100 \mathrm{kN}$ Light Weight Cone Penetrometer System.......................................... 7

Figure 2. Cone Penetrometer Riser Mount Assembly Plan View. ............................................ 8

Figure 3. A.P. van den Berg Trainer Johan de Lange Explains the Cone Penetrometer Software.

Figure 4. Example of Cone Penetrometer GOnsite! $®$ Software Display.................................. 10

Figure 5. Riser Mounting Plate Connection to Spray Ring and Final Assembly. ..................... 12

Figure 6. Cone End Set Assembly ................................................................................... 12

Figure 7. A.P. van den Berg Drawing Showing Integrated Hydraulic Clamp.......................... 17

\section{TABLES}

Table 1. Measurements in Kaolin/Water Mixture. ................................................................ 14

Table 2. Measurements in Kaolin/Sand/Water Mixture...................................................... 14

Table 3. Measurements in Dirt/Water Mixture................................................................. 15 
RPP-RPT-42504 Rev. 0

\section{TERMS}

\section{Abbreviations and Acronyms}

$\begin{array}{ll}\text { BDGRE } & \text { buoyant displacement gas release event } \\ \text { CTF } & \text { Cold Test Facility } \\ \text { DST } & \text { double-shell tank } \\ \text { ROM } & \text { rough order of magnitude } \\ \text { SST } & \text { single-shell tank }\end{array}$

\section{Units}

$\begin{array}{ll}\mathrm{cm} & \text { centimeter } \\ \mathrm{kg} & \text { kilogram } \\ \mathrm{kN} & \text { kilonewton } \\ \mathrm{lb}_{\mathrm{f}} & \text { pounds force } \\ \mathrm{lb}_{\mathrm{m}} & \text { pounds mass } \\ \mathrm{m} & \text { meter } \\ \mathrm{m}^{2} & \text { square meter } \\ \mathrm{m}^{3} & \text { cubic meter } \\ \mathrm{mm} & \text { millimeter } \\ \mathrm{MPa} & \text { megapascal } \\ \mathrm{N} & \text { Newton } \\ \mathrm{Pa} & \text { Pascal } \\ \mathrm{wt} \% & \text { weight percent }\end{array}$




\subsection{INTRODUCTION}

\subsection{PURPOSE}

This report documents evaluation of commercial shear strength measuring equipment for use in Hanford Site double-shell tanks (DSTs). Scope includes equipment selection, procurement and evaluation at the Hanford Site Cold Test Facility (CTF).

\subsection{BACKGROUND}

Radioactive wastes from nuclear fuel processing are stored in large underground tanks. There are 149 older single-shell tanks (SSTs) built in the 1940's through 1960's and 28 newer DSTs built in the 1970's and 1980's. The SSTs contain only negligible amounts of liquid wastes, and the Tank Operations Contractor is continuing a program of moving solid wastes from SSTs to DSTs. Solid wastes can be divided into salt cake (mostly soluble sodium nitrate and nitrite salts with some interstitial liquid consisting of concentrated salt solutions) and sludge (mostly low solubility aluminum and iron compounds with relatively dilute interstitial liquid). Some DSTs store only liquid waste, while others contain both liquid and a layer of settled solids.

Waste generates hydrogen through the radiolysis of water and organic compounds, radiothermolytic decomposition of organic compounds, and corrosion of a tank's carbon steel walls. Nonflammable gases, such as nitrous oxide and nitrogen, are also produced. Additional flammable gases (e.g., ammonia and methane) are generated by chemical reactions between various degradation products of organic chemicals present in the tanks.

Six DSTs containing low shear strength salt cake wastes began showing signs of buoyant instability in the form of periodic waste level drops in the 1980's. Studies in the 1990's indicated that gas would accumulate in the settled solids layer until its bulk density was lower than the supernatant liquid. The resultant gas release caused by this instability was termed a buoyant displacement gas release event (BDGRE) (RPP-7771, Flammable Gas Safety Issue Resolution). Significant gas accumulation and BDGREs have not been observed in tanks containing sludge wastes, which appear to have higher shear strength. Generated gases are evidently released from sludge waste in a nearly continuous manner so that flammability potential can be managed effectively by headspace ventilation. However, it is much more difficult to manage flammability when a large amount of the gas retained within waste is released rapidly in a BDGRE. These releases can potentially create flammable gas concentrations in the tank headspace exceeding the lower flammability limit for short durations. Criteria have been developed to prevent forming new tanks that might be susceptible to BDGREs.

\subsubsection{Current Criteria Based on DST Salt Slurry Behavior}

The criteria used to prevent making new waste configurations that could exhibit BDGREs are based on the behavior observed in low shear strength (average of about $150 \mathrm{~Pa}$ ) waste in the six DSTs that have historically had BDGREs (RPP-10006, Methodology and Calculations for the 
Assignment of Waste Groups for the Large Underground Waste Storage Tanks at the Hanford Site; PNNL-13337, Derivation of the Buoyancy Ratio Equation from the Bubble Migration Model). BDGRE behavior is evaluated using two criteria, the buoyancy ratio and the energy ratio.

While all radioactive tank wastes generate gas, most DSTs do not have buoyant displacements. This indicates that tanks generally achieve balance between gas generation and a quasi steady state background gas release. The mechanism for this quasi steady state background release is unknown, but it must exist or all DSTs with settled solids would experience BDGREs. The phenomenon has been modeled by theorizing the slow migration (percolation) of bubbles through the settled solids. The steady state retained gas volume fraction is then dependent on the gas generation rate and bubble migration rate. The ratio of the retained gas volume fraction to that required for the solids layer to become buoyant is called the buoyancy ratio. If the bubble migration is too slow, the retained gas volume fraction can exceed buoyancy, i.e., the buoyancy ratio exceeds unity, and a BDGRE may occur.

For a BDGRE to be possible, the event must release enough mechanical energy to yield the solids and release the gas (i.e., exceed the energy ratio). The amount of energy available depends on the driving force and distance the buoyant solids rise which depends on the supernatant liquid depth and the retained gas volume fraction at buoyancy. The amount of energy required is proportional to the solids shear strength. Unless the ratio of energy available to energy required is sufficiently large, a large gas release cannot occur even if the waste sediments become buoyant.

Though the buoyancy ratio and energy ratio include the effects of the material strength, the methods have been correlated only to the few DSTs that have (or have had) BDGREs. These tanks have relatively low shear strength and early tests showed (PNNL-11298, Mechanisms of Gas Bubble Retention and Release: Results for Hanford Waste Tanks 241-S-102 and 241-SY-103 and Single-Shell Tank Simulants) gas was retained in small, discrete bubbles. When the criteria are extended to include stronger wastes, the result is restrictive (PNNL-15238, Predicting Peak Hydrogen Concentrations from Spontaneous Gas Releases in Hanford Waste Tanks). However, the same early tests also showed that stronger wastes retain gas in the form of long, irregular "dendritic" bubbles formed by local mechanical failure of the solid matrix rather than individual bubbles rising through the medium. These failures can form cracks that remain open and release gas continuously. If practical criteria for occurrence of open cracks that prevent BDGREs can be derived, application of the restrictive buoyancy ratio would not be required.

\subsubsection{Proposed Criteria Based on Dutch Work}

Delft Hydraulics examined the effect of gas production on the storage capacity of artificial sludge depots ["Gas Production and Transport in Artificial Sludge Depots" (van Kessel and van Kesteren 2002)]. Decomposition of organic material present in dredging spoil produces methane and carbon dioxide. Studies showed that gas accumulation occurs as convective and diffusive transport proceeds very slowly. Gas bubbles nucleate and grow, pushing aside the surrounding grain matrix. Resulting stresses initiate cracks around bubbles. If these cracks join, 
they form channels stretching to the sediment surface along which gas can escape. However, channels are only stable to a limited depth below which bubble accumulation may continue until the sediments achieve buoyancy.

The gas content at which sufficient cracks and channels are formed to balance the rate of gas production with the rate of outflow strongly depends on the constitutive properties of the dredging sludge. Maximum channel depth is dependent on the waste properties shown below in Equation 1 (van Kessel and van Kesteren 2002).

$$
d_{\max }=\frac{c_{u}(1+e)}{K_{0}\left(\rho_{d s}-\rho_{\ell}\right) g} \times\left[1+\ln \left(\frac{r_{0}^{2}-d_{f}^{2}}{d_{f}^{2}}\right)+\ln \left(\frac{E}{2 c_{u}(1+v)}\right)\right]
$$

Where $d_{\max }=$ maximum stable channel depth, $\mathrm{m}$

$c_{u}=$ shear strength, $\mathrm{Pa}$

$e=$ void ratio, dimensionless

$K_{0}=$ ratio between horizontal and vertical effective stress, dimensionless

$\rho_{d s}=$ dry settled solids density, $\mathrm{kg} / \mathrm{m}^{3}$

$\rho_{\ell}=$ liquid density, $\mathrm{kg} / \mathrm{m}^{3}$

$r_{0}=$ undisturbed channel radius, $\mathrm{m}$

$d_{f}=$ median floc size, $\mathrm{m}$

$E=$ modulus of elasticity, $\mathrm{Pa}$

$v=$ Poisson ratio, dimensionless

In situ shear strength has never been measured in sludge wastes, but estimates suggest that Hanford waste sludges have shear strengths an order of magnitude higher than measured in salt cake wastes. The theory developed by Delft might explain why significant gas accumulation and BDGREs have not been observed in sludge tanks, and allow for higher solids accumulation in the DSTs for high shear strength wastes. Analysis, development and implementation of new BDGRE criteria require waste shear strength measurements, and that measurement technology must be adapted for use in DSTs. 


\subsection{EQUIPMENT SELECTION}

\subsection{PERFORMANCE CRITERIA}

The shear strength measuring tool selected must overcome constraints imposed by tank configuration and the waste. Sludge shear strengths are estimated to fall between 500 and 4,000 Pa (RPP-10006) and the waste will be highly caustic (hydroxide concentration greater than 1 Molar). In situ measurements are currently planned for tanks 241-AN-101, 241-AN-106, 241-AY-101 and 241-AZ-101, so deployment will most likely be through risers ranging between six and twelve inches in diameter. A nearly complete shear strength profile through the sludge waste is important because $\mathrm{d}_{\max }$ is determined iteratively (i.e., all points through the waste depth must be able to support a drainage channel that reaches the sludge waste surface).

The tool selected should measure in situ shear strengths ranging between 0 to $20,000 \mathrm{~Pa}$ (sludge wastes should easily fall within this range) with a desired resolution/accuracy of $\pm 100 \mathrm{~Pa}$. The tank penetrating portion must be less than $15 \mathrm{~cm}$ in diameter so that it can pass through a 6 inch riser. Measurement depth will be up to $20 \mathrm{~m}$. The first about 10 to $15 \mathrm{~m}$ is an air gap, the next about 1 to $5 \mathrm{~m}$ would most likely be caustic liquid waste, and the bottom $5 \mathrm{~m}$ is the waste solids. The waste penetration portion (liquid and solids) should not contain aluminum parts because the waste is highly caustic. Shear strength measurements should be near continuous $(\leq 5 \mathrm{~cm}$ intervals) through the waste solids layer.

\subsection{REQUEST OF INTEREST}

A Request of Interest for a Double-Shell Tank Waste In Situ Shear Strength Measurement Tool was posted on the Federal Business Opportunity web site in January 2009 stating the above performance criteria. Interested firms were invited to submit an expression of interest letter that included the following:

1. A description of their system/technical approach.

2. A preliminary drawing/sketch of their concept.

3. A rough order of magnitude (ROM) cost estimate for all components.

4. A ROM schedule and any qualifying conditions for meeting the schedule.

5. A brief description of Quality Program.

Three companies initially responded and two companies provided expression of interest letters in late February 2009. Details are proprietary, but the two cost estimates were $\$ 400,000$ and $\$ 471,000$ and both systems required some development work. ROM schedules showed system deliveries in November 2009 and July 2010, respectively. A literature search and vendor survey were conducted while waiting for expression of interest responses to find an existing system that might be adapted quickly at low cost. 


\subsection{LITERATURE SEARCH \& VENDOR SURVEY}

\subsubsection{Technologies Considered}

Technologies capable of measuring DST waste in situ shear strength were examined in the 1990's and included ball rheometer (PNNL-11296, In Situ Rheology and Gas Volume in Hanford Double-Shell Waste Tanks), shear vane (SD-WM-TC-005, Test Procedure for Use of the Shear Vane in Tanks 103-SY, 103-AN, and 103-AW) and cone penetrometer (WHC-SD-WM-SDD-063, System Design Description Cone Penetrometer System). Only the ball rheometer was deployed and measurements were made in six salt slurry tanks (241-AN-103, 241-AN-104, 241-AN-105, 241-AW-101, 241-SY-101 and 241-SY-103).

The ball rheometer consisted of a $71-\mathrm{N}\left(16 \mathrm{lb}_{\mathrm{f}}\right), 9.12-\mathrm{cm}$ (3.59 inches) tungsten alloy ball tethered to a steel cable that was let out and retrieved from a spool at precise speeds. A load cell measured tension in the cable as the ball was allowed to slowly sink through the waste. Shear strength (yield stress in shear) was derived from the drag force as the ball moved through the waste at various speeds. DST salt slurry non-convective waste shear strengths ranged between 100 and $250 \mathrm{~Pa}$. The ball rarely reached tank bottom as buoyancy and resistance on the ball/cable prevented characterization of the bottom meter of waste (PNNL-11296). The ball rheometer would likely fail to penetrate to the bottom of the higher shear strength sludge waste layers and was not selected.

The shear vane offered what appeared at first to be a low cost alternative for measuring in situ shear strength; however, two issues made shear vane a less than optimum solution. The first is that it does not allow for a near continuous measurement of in situ shear strength. The shear vane used in the Dutch experiments (Factual Report DM10, In-Situ Metingen Slibtank) had fins measuring $114 \mathrm{~mm}$ (4.49 inches) tall and $76 \mathrm{~mm}$ (2.99 inches) wide. The shear vane disturbs a region of waste around the fin and the vane is typically deployed in $0.5 \mathrm{~m}$ (19.7 inch) depth increments. The second issue is that the shaft has some drag when the vane blade is rotated during the test. Vane shaft drag is corrected by repeating the measurement with only the shaft (substituting a pointed end piece for the vane blade) and this force is subtracted from the vane blade measurement. Two measurements are often necessary to get one accurate value.

Cone penetrometers were judged to offer the best opportunity to meet the desired performance criteria. The cone contains the load cell and tip resistance is converted into shear strength. Corrections for friction on cone penetrometer rods are not necessary because strain is measured at the tip. Measurements would be near continuous as the cone tip moves through the waste sediment layer. 


\subsubsection{Potential Cone Penetrometer Vendors}

Three cone penetrometer manufactures were contacted, Applied Research Associates, Inc. (Vertek Cone Penetrometer Products) located in Vermont, and two Dutch companies, A.P. van den Berg and GeoMil. A.P. van den Berg had ready-made equipment and provided open literature references showing experience in making cone penetrometer systems for measuring in situ shear strength of soft silts and muds. A T-bar is added to the existing cone penetrometer to increase resolution [Adapted T-Bar Penetrometer versus CPT to Determine Undrained Shear Strengths of Dutch Soft Soils (Oung et al. 2004); Charterisation of Soft Sediments for Offshore Applications (Randolph 2004)]. The shear strength of soft silts and muds are similar to the expected shear strengths of Hanford Site sludge wastes. Both GeoMil and Vertek stated they could provide suitable cone penetrometer systems, but development efforts would be reflected in delivery schedule and equipment costs. The A.P. van den Berg Hyson 100-kN Light Weight Cone Penetrometer was selected for evaluation. A stock unit with a T-Bar cone tip was procured to determine whether this system could be adapted for use measuring in situ shear strength in DST sludge waste. The complete Hyson $100 \mathrm{kN}$ cone penetrometer system was less than $\$ 57,000$ and could be delivered in under three months. 


\subsection{INITIAL EVALUATION}

Equipment was ordered on February 24, 2009 and arrived 11 weeks later on May 11, 2009. The Hyson $100 \mathrm{kN}$ Light Weight Cone Penetrometer is designed to perform in situ geotechnical soil investigations in locations inaccessible to other equipment, such as basements, back yards, swampy and overgrown land. The cone penetrometer system major components included a single-cylinder hydraulic ram, a hydraulic power pack, an I-Control data logger, I-Cone digital cone with T-Bar and measuring cables, and 40 rods measuring $500 \mathrm{~mm}$ (19.68 inches) long and $36 \mathrm{~mm}$ (1.42 inches) in diameter. The T-Bar measured $120 \mathrm{~mm}$ (4.72 inches) long, $25 \mathrm{~mm}$ (0.98 inches) in diameter and $285 \mathrm{~mm}$ (11.22 inches) tall. The system is light weight with the penetrometer weighing $85 \mathrm{~kg}(187 \mathrm{lb}$ ) and the power pack (after filling with hydraulic fluid) weighing about $112 \mathrm{~kg}(247 \mathrm{lb}$ ). The penetrometer is designed to be fixed in place (see stock photo in Figure 1) using aluminum cross bars and four soil anchors.

Figure 1. Hyson $100 \mathrm{kN}$ Light Weight Cone Penetrometer System.

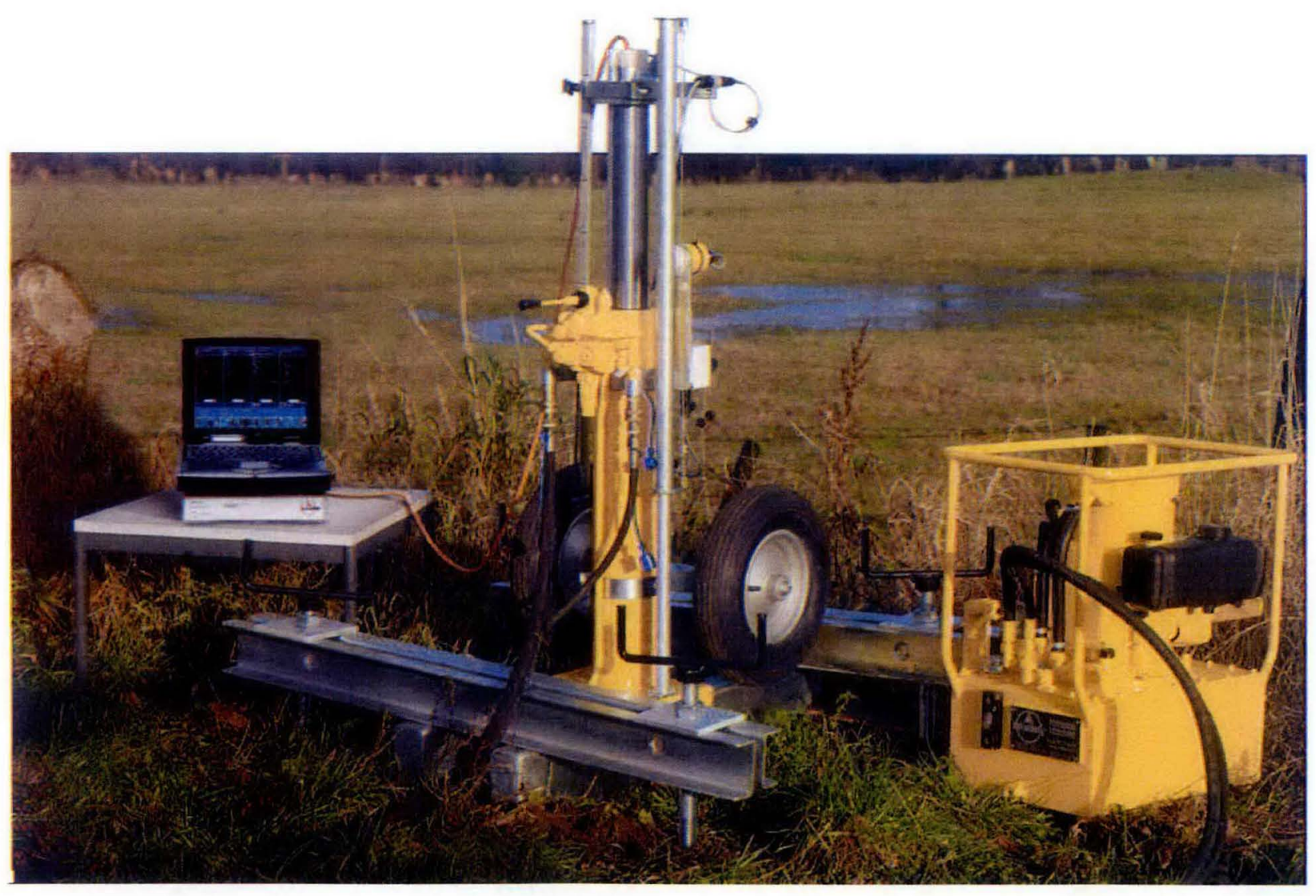


Initial evaluation included equipment inspection and review of the operating instructions by subject matter experts (e.g., nuclear power operators, engineering, Rad Con and Industrial Safety). Two issues were identified during initial evaluation. The first was how to anchor the penetrometer given that the current stock anchoring system was not suitable for deployment in a DST riser. The solution was to mount the penetrometer base to a riser using a mounting plate coupled with an existing spray ring design (see Figure 2 and Drawing H-14-107715, Penetrometer Base/Riser Connection Details).

Figure 2. Cone Penetrometer Riser Mount Assembly Plan View.

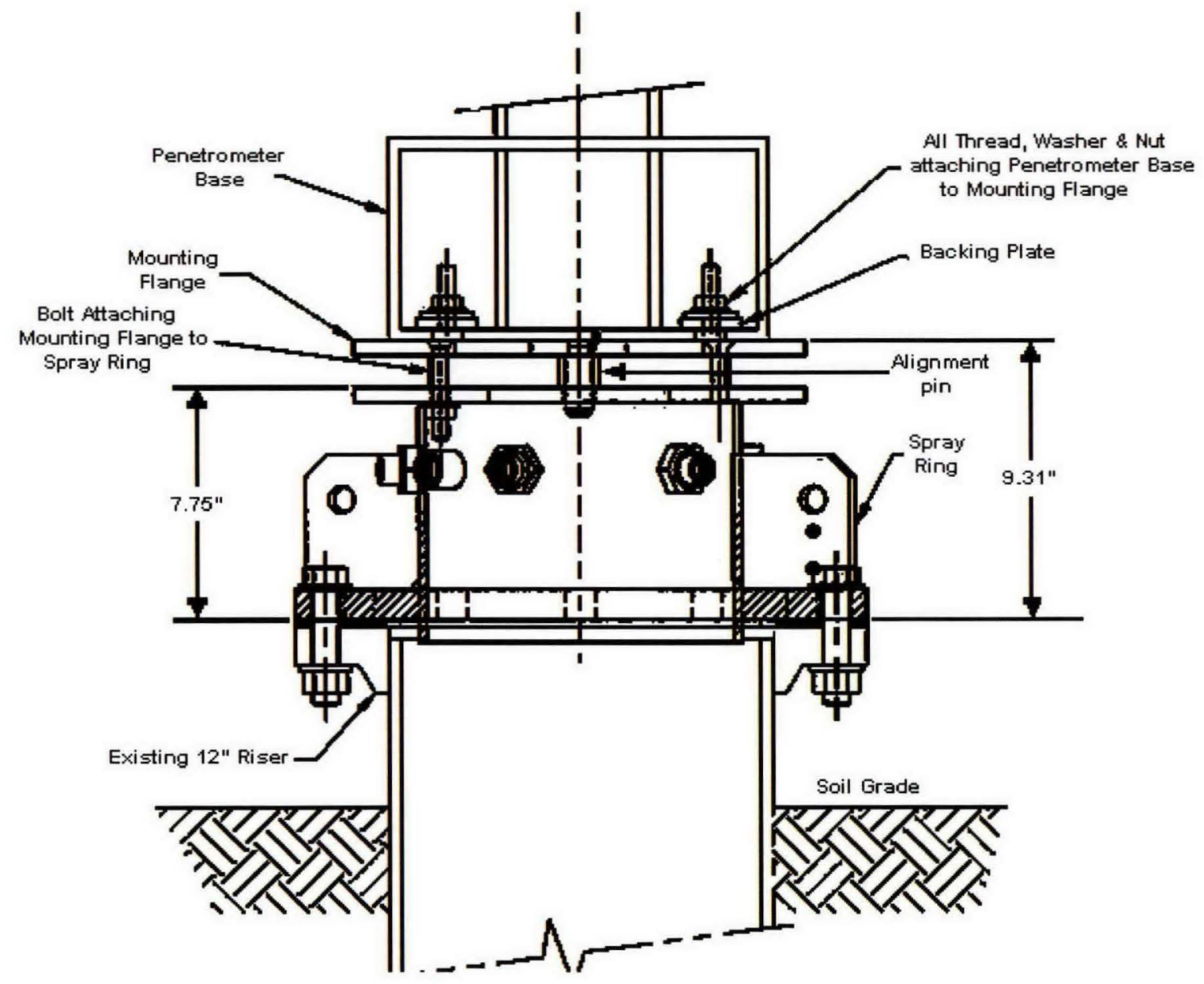

The second issue was the electrical listing on the I-Control data logger. The data logger requires a standard 110 volt power supply and contained only a CE marking. The European CE marking is a self declaration where the manufacturer declares conformity with European electrical standards by signing the Declaration of Conformity and then affixes the CE Mark on the product. Electrical equipment used in tank farms requires an Underwriter's Laboratory or equivalent rating so a contract was placed with TUV Rheinland of North America for an electrical evaluation. Testing showed that the I-Control data logger met the necessary electrical safety standards and a Nationally Recognized Testing Laboratories mark was placed on the data logger. 


\subsection{COLD TEST FACILITY EVALUATION}

The Hyson $100 \mathrm{kN}$ cone penetrometer system operates by feeding rods through the penetrometer until the T-bar penetrates to the desired depth. The cone load cell transmits T-bar cone tip resistance to the I-Control data logger through the I-Cone measuring cable strung through the rods. Force is recorded on a lap top computer (using the proprietary GOnsite! ${ }^{\circledR}$ software) which is connected to the I-Control data logger through a USB cable.

The cone penetrometer was evaluated at CTF in August 2009. Penetrometer operation was performed under assistance and direction of a qualified trainer provided by the manufacturer (A.P. van den Berg). Evaluation included installation and operation of software and electrical components, connection of the cone penetrometer base, mounting flange and spray ring to a simulated 12-inch riser, and testing of the system in three mixtures (kaolin/water, soil/water and $\mathrm{kaolin} / \mathrm{sand} /$ water).

\subsection{SOFTWARE AND ELECTRICAL COMPONENTS}

The software and electrical components were tested before attempting any measurements. The proprietary GOnsite! ${ }^{\circledR}$ software was installed on a lap top computer and the I-Control data logger was connected to a lap top computer. The I-Cone with T-bar attached was connected to the I-Control data logger, and the data logger powered up (see Figure 3).

Figure 3. A.P. van den Berg Trainer Johan de Lange Explains the Cone Penetrometer Software.

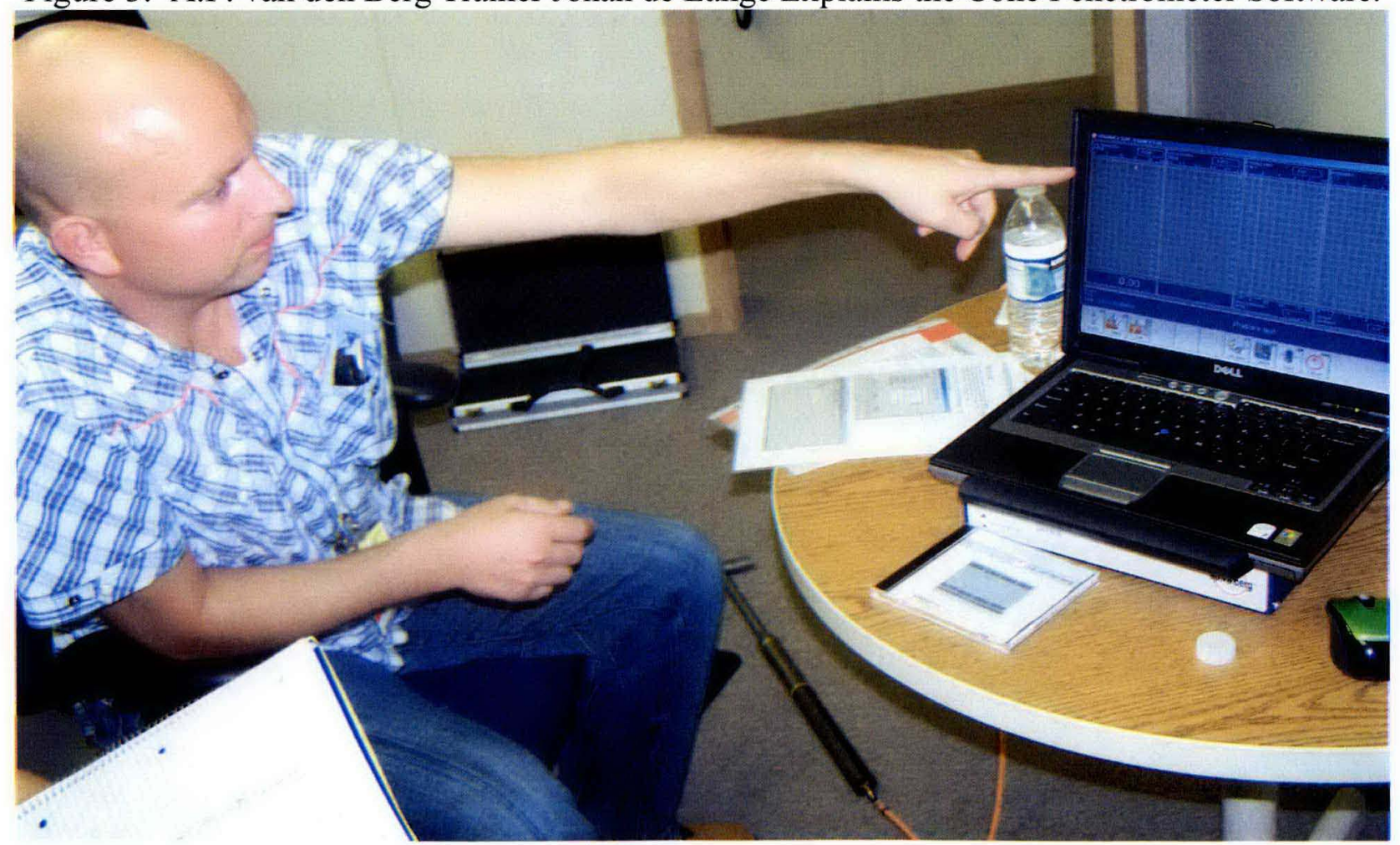


GOnsite!® software does not automatically detect the I-Control data logger com port. Operating software installed I-Control drivers and assigned the com port, but the GOnsite! $®$ software was manually configured to the assigned com port. Once the com port was selected, a small icon in the lower right hand corner showed a wavy green line while the system was powered and connected. The electronics are functioning correctly when the icon shows a sine wave pattern (called a heartbeat by the trainer).

The display selected showed three data boxes, tip resistance, friction ratio and inclination (Figure 4). The tip resistance display readings are in MPa but the display and data collected while the T-bar is connected actually represents force in $\mathrm{kN}$. Depth in meters is shown on the right hand side of each data box. The second data box shows friction ratio which involves cone tip friction and resistance on the friction sleeve. This property is not needed for determining shear strength and therefore is not measured. The third data box shows inclination of the cone in the xy plane. Inclination should be as near zero as possible during operation to ensure the rods are traveling vertically in the $\mathrm{z}$ direction. If inclination exceeds more than about $20 \%$, the moment created by the T-bar might damage the cone load cell.

Figure 4. Example of Cone Penetrometer GOnsite! $®$ Software Display.

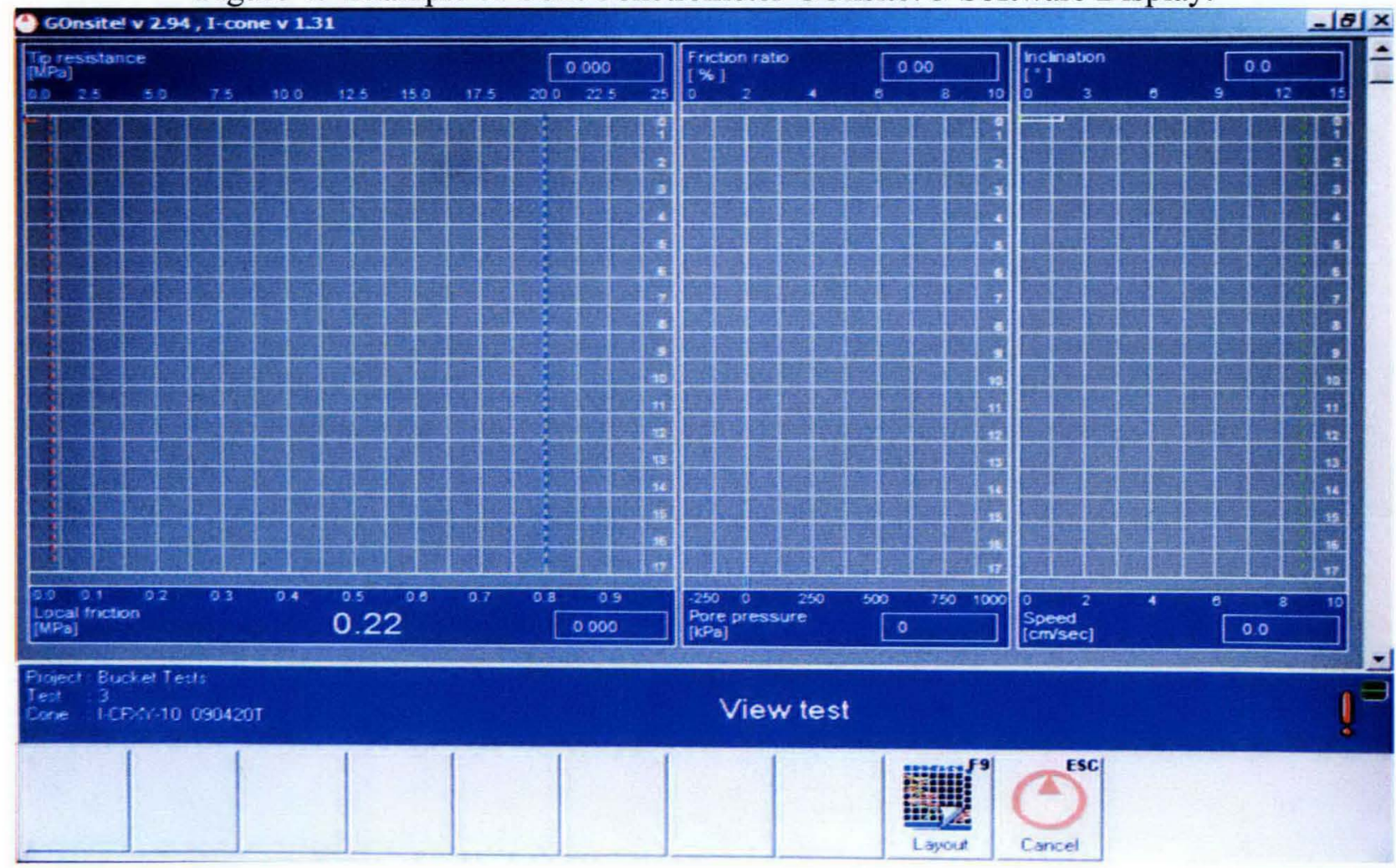

Forces experienced by the T-Bar will most likely be less than $1 \mathrm{kN}$ until the T-Bar impacts a hard obstacle (e.g., tank bottom) so the real-time display is not currently helpful because of the display scale. A.P. van den Berg is updating the software to display in $\mathrm{N}$ to provide a more useful real-time display. Data is collected in $0.001 \mathrm{kN}$ increments so the proper data is collected, just not displayed in real-time. The software can be set to alarm at a specific force to detect excessive pressure on the cone load cell. The software was set to alarm at $1 \mathrm{kN}$ during testing. 
The English version of the software had some untranslated Dutch which will be corrected by the A.P. van den Berg software engineer. The untranslated Dutch was in the test background information section and did not affect data collection or display. Specifically, Plaats = Place (the location the test was conducted), Sondeer $\mathrm{nr}=$ sounding number (the cone penetrometer identification number) and Dag $\mathrm{nr}=$ Day number (the date of the test).

When a test is started, an initial xy incline and initial cone load cell reading are displayed and recorded. This initial data is called the zero point. After significant use, the cone load cell wears and when the cone reads more than $10 \%$ difference from the beginning and ending zero points, it must be recalibrated to give accurate measurements. This is unlikely to occur during DST waste measurements in that the cone and rods will become contaminated and current plans are dispose or these relatively low cost items after an in situ measurement.

\subsection{RISER MOUNT ASSEMBLY}

The spray ring was connected to a 12 inch simulated riser at CTF, then the mounting plate was connected to spray-ring and finally the penetrometer attached to the mounting plate (Figure 5). The end set (see Figure 6) was assembled as directed by the trainer. Opinion among subject matter experts was that the process would be improved by preassembling the mounting plate, rod wiper seal, initial cone set and T-Bar, and then attaching the preassembled cone penetrometer unit to the riser.

The hydraulic power pack and electronics were connected and the cone penetrometer system powered up. An initial observation was that the hydraulic power pack had no choke and was difficult to start. After about 10 minutes, the power pack engine started leading to another observation that the power pack gasoline engine is loud. The hydraulic lines are $5 \mathrm{~m}$ long and if these lines were three times longer, this would place people farther away from the noise and exhaust of the power pack. The Dutch trainer also stated that an electrically driven power pack might be supplied, but would add incrementally to the overall system cost.

The cone penetrometer as configured can push with a force of up to $100 \mathrm{kN}\left(\sim 22,500 \mathrm{lb}_{\mathrm{f}}\right)$. The goal is to measure in situ shear strength to as near the tank bottom as practicable. Several practices developed for core sampling will be utilized to ensure the tank liner is not damaged including measurement of riser height and marking the final rod to know when to stop penetration. Even with a T-bar attachment, such force might hypothetically damage a tank liner. Although the software was set to alarm once the T-bar experiences a force greater than $1 \mathrm{kN}$ $\left(\sim 225 \mathrm{lb}_{\mathrm{f}}\right)$, the cone penetrometer system does not have an automatic interlock. Two simple solutions were proposed. The A.P. van den Berg representative stated that the power pack could be regulated so that the ram could not push with more force than would be safe against the bottom of the tank. A second solution would be to mount the cone penetrometer with guiding pins rather than bolting the system to the riser. If a resistance of more than about $400 \mathrm{lb}_{\mathrm{f}}$ was experienced (total mass of the cone penetrometer with rods would be about $400 \mathrm{lb}_{\mathrm{m}}$ ), then the cone penetrometer would rise on guiding pins before hypothetically damaging the tank liner. 
Figure 5. Riser Mounting Plate Connection to Spray Ring and Final Assembly.
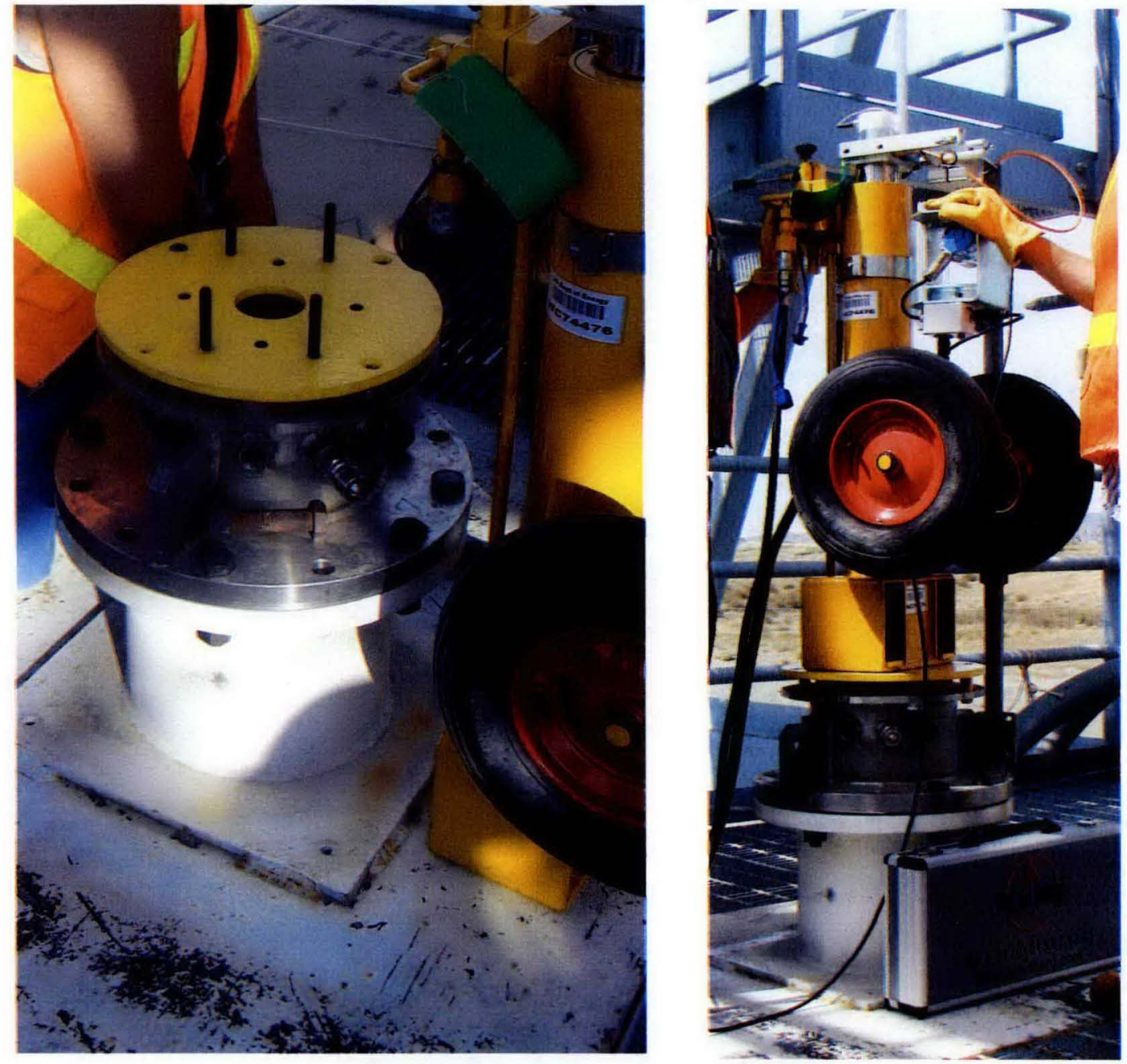

Figure 6. Cone End Set Assembly

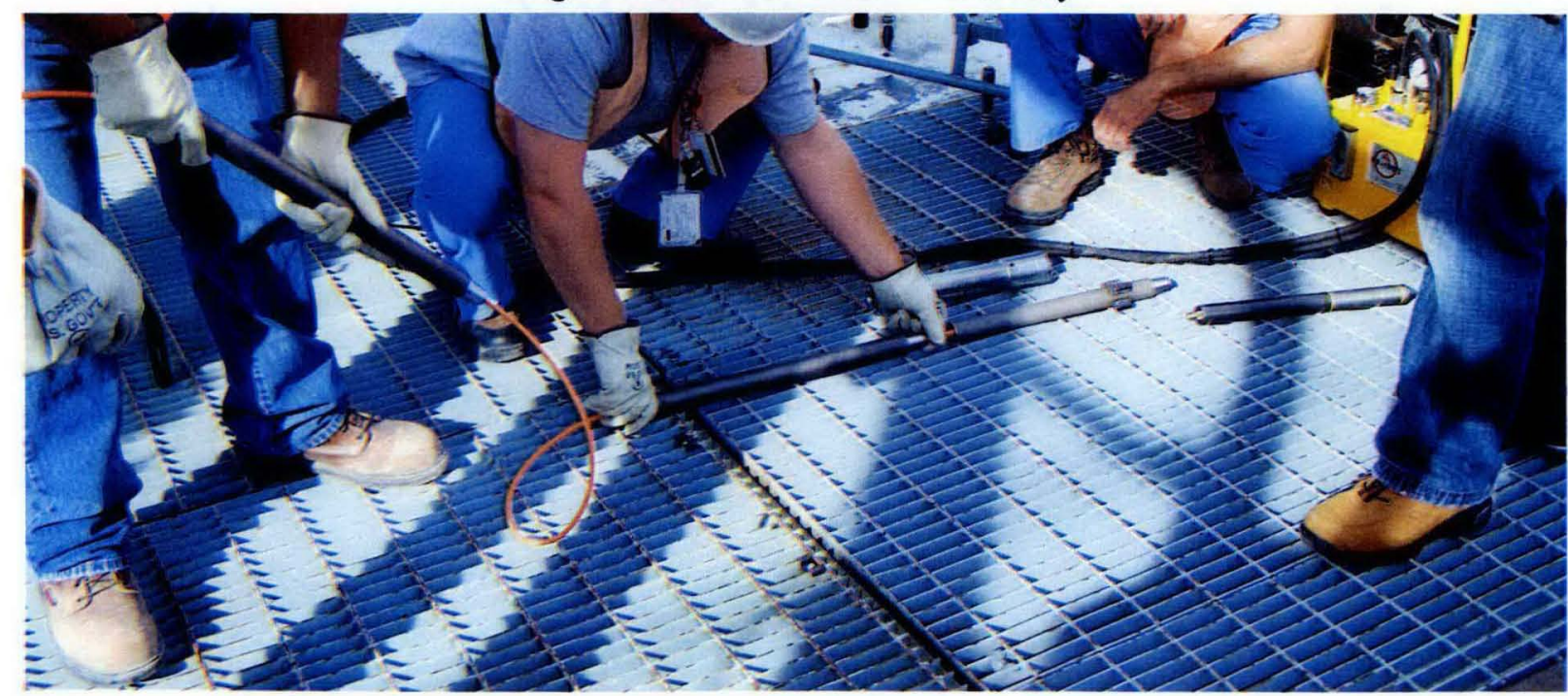


The stock Hyson $100 \mathrm{kN}$ cone penetrometer system comes with mechanical push/pull clamps. When operating with the stock clamps, the rod string is pulled back through the penetrometer approximately $2 \mathrm{~cm}$ ( 0.79 inches) to help disengage the clamp. This poses both a contamination concern and greater opportunity for the rod string to slip while making measurements. The A.P. van den Berg representative stated that hydraulic clamps they manufacture for their larger systems might be integrated into the Hyson $100 \mathrm{kN}$ cone penetrometer. The hydraulic clamps would be operated via the existing power pack and would eliminate the need to move the rod string to help disengage the mechanical clamp and provide a secure hold at all times on the rod string. Subject matter expert consensus was to have A.P. van den Berg provide a cost estimate for integrating hydraulic clamps.

\subsection{MEASUREMENTS}

Shear strength is calculated using the projected area of the T-bar, which in this case is $0.003 \mathrm{~m}^{2}$ (the cylinder has a $25 \mathrm{~mm}$ diameter and $120 \mathrm{~mm}$ length). As shown in Equation 2, undrained shear strength is simply the measured force per unit area divided by the T-bar $\mathrm{N}$ factor. The recommended intermediate T-bar $\mathrm{N}$ factor is 10.5 (Stewart and Randolph, T-Bar Penetration Testing in Soft Clay).

$$
c_{u}=\frac{F}{0.003 m^{2} \times N_{b}}
$$

Where $\quad \mathrm{c}_{\mathrm{u}}=$ undrained shear strength, $\mathrm{Pa}$

$\mathrm{F}=$ force measured by $\mathrm{T}$-bar, $\mathrm{N}$

$\mathrm{N}_{\mathrm{b}}=\mathrm{T}$-bar $\mathrm{N}$ factor, 10.5 , dimensionless

Three mixtures were tested during cone penetrometer demonstration. The test goals were to familiarize staff with operation and data collection on a range of materials. The first mixture was $\mathrm{kaolin} /$ water and contained approximately $50 \mathrm{wt} \%$ kaolin. The kaolin/water mixture was allowed to sit for six days (in a covered container) before testing. This mixture was expected to have a shear strength ranging between 100 and $200 \mathrm{~Pa}$ based on earlier work (PNNL-14333, Physical and Liquid Chemical Simulant Formulations for Transuranic Wastes in Hanford Single-Shell Tanks). The kaolin/water mixture was placed in a 2-gallon container having a $240 \mathrm{~mm}$ diameter and $230 \mathrm{~mm}$ depth. Results are shown in Table 1.

Table 1 shows that the cone penetrometer system responded well in the low strength material tested. This represents the lowest end of anticipated sludge shear strength. Results were surprising close to previous experiments (PNNL-14333) given the expected edge effect bias introduce by testing in small containers. Cone penetrometer calibration chamber tests (Wesley, Interpretation of Calibration Chamber Tests Involving Cone Penetrometers in Sands) show a bias towards higher measurements when chamber to cone diameter ratios were less than 60 . This will not be an issue in the large diameter DSTs. 
Table 1. Measurements in Kaolin/Water Mixture.

\begin{tabular}{|c|c|c|}
\hline $\begin{array}{c}\text { Depth } \\
(\mathbf{m})\end{array}$ & $\begin{array}{c}\text { Force } \\
(\mathbf{k N})\end{array}$ & $\begin{array}{c}\text { Calculated } \mathbf{C}_{\mathbf{u}} \\
(\mathbf{P a})\end{array}$ \\
\hline 0.02 & 0.003 & 95 \\
\hline 0.04 & 0.006 & 190 \\
\hline 0.06 & 0.007 & 222 \\
\hline 0.08 & 0.008 & 254 \\
\hline 0.10 & 0.007 & 222 \\
\hline 0.12 & 0.007 & 222 \\
\hline 0.14 & 0.007 & 222 \\
\hline 0.16 & 0.009 & 286 \\
\hline 0.18 & 0.010 & 317 \\
\hline 0.20 & $0.787^{*}$ & $\mathrm{NA}$ \\
\hline
\end{tabular}

Note: * Alarm when greater than $1.000 \mathrm{kN}$ force reached at the bottom. Test was stopped.

NA $=$ Not Applicable

The second mixture tested was sand/kaolin/water and contained about $50 \mathrm{wt} \%$ sand, $20 \mathrm{wt} \%$ kaolin and $30 \mathrm{wt} \%$ water. Wetted sand was placed in a similar 2 gallon container and then combined with the existing kaolin/water mixture. The sand/kaolin/water was mixed for about ten minutes until a uniform consistency (about like creamy peanut butter) was achieved. The mixture was tested within about 15 minutes of preparation and results are shown in Table 2 . The cone penetrometer system responded well to the mid-range material.

Table 2. Measurements in Kaolin/Sand/Water Mixture.

\begin{tabular}{|c|c|c|}
\hline $\begin{array}{c}\text { Depth } \\
(\mathbf{m})\end{array}$ & $\begin{array}{c}\text { Force } \\
(\mathbf{k N})\end{array}$ & $\begin{array}{c}\text { Calculated } \mathbf{C}_{\mathbf{u}} \\
(\mathbf{P a})\end{array}$ \\
\hline 0.02 & 0.005 & 159 \\
\hline 0.04 & 0.016 & 508 \\
\hline 0.06 & 0.036 & 1,140 \\
\hline 0.08 & 0.054 & 1,710 \\
\hline 0.10 & 0.079 & 2,510 \\
\hline 0.12 & 0.095 & 3,020 \\
\hline 0.14 & 0.101 & 3,210 \\
\hline 0.16 & 0.096 & 3,050 \\
\hline 0.18 & 0.100 & 3,180 \\
\hline 0.20 & 0.097 & 3,080 \\
\hline 0.22 & $0.540^{*}$ & NA \\
\hline
\end{tabular}

Note: *Alarm when greater than $1.000 \mathrm{kN}$ force reached at the bottom. Test was stopped.

$\mathrm{NA}=$ Not Applicable

The third mixture was soil and water. Dry soil was placed into a 2 gallon container and water added on top. Water was added incrementally and the sample hand stirred from the top down. The soil/water was not mixed to a uniform consistency, rather the bottom portion was left considerably drier than the top with a gradation between the wet surface and relatively dry bottom. The mixture was immediately tested after preparation and results are shown in Table 3. As expected, results show a significant gradation with depth. The test was stopped a little over halfway through the test material when a force of greater than $1 \mathrm{kN}$ was reached. 
RPP-RPT-42504 Rev. 0

Table 3. Measurements in Dirt/Water Mixture.

\begin{tabular}{|c|c|c|}
\hline $\begin{array}{c}\text { Depth } \\
(\mathbf{m})\end{array}$ & $\begin{array}{c}\text { Force } \\
(\mathbf{k N})\end{array}$ & $\begin{array}{c}\text { Calculated } \mathbf{C}_{\mathbf{u}} \\
(\mathbf{P a})\end{array}$ \\
\hline 0.02 & 0.014 & 444 \\
\hline 0.04 & 0.024 & 762 \\
\hline 0.06 & 0.031 & 984 \\
\hline 0.08 & 0.043 & 1,370 \\
\hline 0.10 & 0.210 & 6,670 \\
\hline 0.12 & $0.875^{*}$ & 27,800 \\
\hline
\end{tabular}

Note: * Alarm, T-bar reached dry region of dirt/water mixture and exceeded $1.000 \mathrm{kN}$ of force and test was stopped. 


\subsection{RECOMMENDED CHANGES}

Some changes to the cone penetrometer system were recommended based on evaluation at CTF. Recommendations are the following:

- The GOnsite! $®$ software should be upgraded to display real-time force measurements in $\mathrm{N}$ rather than $\mathrm{kN}$ for this unique application at the Hanford Site.

- The hydraulic lines from the power pack to the hydraulic ram should be increased in length from $5 \mathrm{~m}$ to $15 \mathrm{~m}$.

- Switching from a gasoline power pack to an electrical power pack should be considered.

- The hydraulic power pack should be regulated to push with a force considerably less than $100 \mathrm{kN}$.

- A hydraulic clamp should be integrated into the current cone penetrometer.

On completion of the evaluation at CTF, A.P. van den Berg examined the recommended changes to provide potential pricing. Figure 7 is an A.P. van den Berg conceptual drawing showing an integrated hydraulic catching clamp added to the Hyson $100 \mathrm{kN}$ Light Weight Cone Penetrometer. Proposed modifications including the hydraulic catching clamp, $15 \mathrm{~m}$ hydraulic hoses, hydraulic valve to keep pushing force to no more than $30 \mathrm{kN}$, and upgrade to an electric power pack were estimated to cost less than $\$ 13,000$. This would bring the total modified system cost to just under $\$ 70,000$. 


\section{RPP-RPT-42504 Rev. 0}

Figure 7. A.P. van den Berg Drawing Showing Integrated Hydraulic Clamp.

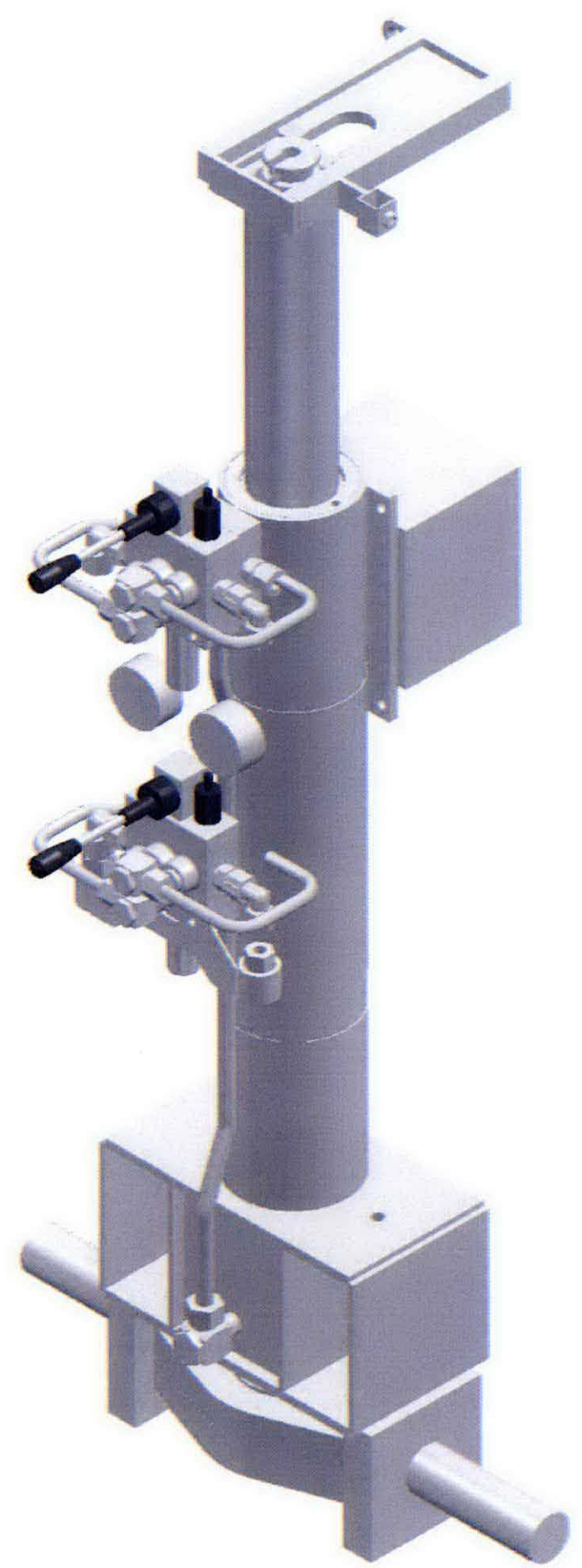




\subsection{CONCLUSIONS}

In situ shear strength measuring equipment is needed for implementation of less restrictive BDGRE criteria. This equipment is not currently available at Tank Farms so a Request of Interest was posted and two companies provided expression of interest responses. Both proposals cost more than $\$ 400,000$ and required development. The soonest a system could be provided for initial CTF evaluation was 10 months. A cone penetrometer system provided the greatest opportunity to meet the desired performance criteria. The Hyson $100 \mathrm{kN}$ Light Weight Cone Penetrometer manufactured by A.P. van den Berg was selected for evaluation and a complete cone penetrometer system was procured for under $\$ 57,000$ in just 11 weeks.

Initial examination identified how the cone penetrometer might be adapted for use in DSTs. A mounting plate was fabricated so that the cone penetrometer could be attached directly to a spray ring/riser assembly. Evaluation at CTF demonstrated that equipment was suitable for use in Tank Farms. The evaluation identified a few recommended changes before deployment in DSTs. Recommendations included small changes to the software, a modified hydraulic power pack and addition of a hydraulic catching clamp. These recommended changes were estimated by A.P. van den Berg to cost less than $\$ 13,000$. The modified system cost estimate is just under $\$ 70,000$, nearly one sixth the lowest cost estimate provided in the expression of interest responses. A complete cone penetrometer system was procured and evaluated at CTF in less than six months, less than half the shortest schedule in the expression of interest responses. 
RPP-RPT-42504 Rev. 0

\subsection{REFERENCES}

Factual Report DM10, 1998, In-Situ Metingen Slibtank, 96-145/A, Waterloopkundig Laboratorium 1997, The Netherlands.

H-14-107715, 2009, Penetrometer Base/Riser Connection Details, Rev. 0, Washington River Protection Solutions, Richland, Washington.

Oung, O., J. W. G. van der Vegt, L. Tiggelman and H. E. Brassinga , 2004, Adapted T-Bar Penetrometer Versus CPT to Determine Undrained Shear Strengths of Dutch Soft Soils, GeoDelft, Delft, The Netherlands.

Randolph, M. F., 2004, "Characterisation of Soft Sediments for Offshore Applications," in $2^{\text {nd }}$ International Conference on Site Characterisation Conference Proceedings, Porto, Portugal, Vol. 1, pp. 209-232.

PNNL-1 1296, 1996, In Situ Rheology and Gas Volume in Hanford Double-Shell Waste Tanks, Rev. 0, Pacific Northwest National Laboratory, Richland, Washington.

PNNL-11298, 1996, Mechanisms of Gas Bubble Retention and Release: Results for Hanford Waste Tanks 241-S-102 and 241-SY-103 and Single-Shell Tank Simulants, Rev. 0, Pacific Northwest National Laboratory, Richland, Washington.

PNNL-13337, 2005, Derivation of the Buoyancy Ratio Equation from the Bubble Migration Model, Addendum 1, Pacific Northwest National Laboratory, Richland, Washington.

PNNL-14333, 2003, Physical and Liquid Chemical Simulant Formulations for Transuranic Wastes in Hanford Single-Shell Tanks, Rev. 0, Pacific Northwest National Laboratory, Richland, Washington.

PNNL-15238, 2005, Predicting Peak Hydrogen Concentrations from Spontaneous Gas Releases in Hanford Waste Tanks, Rev. 0, Pacific Northwest National Laboratory, Richland, Washington.

RPP-7771, 2001, Flammable Gas Safety Issue Resolution, Rev. 0A, CH2M HILL Hanford Group, Inc., Richland, Washington.

RPP-10006, 2009, Methodology and Calculations for the Assignment of Waste Groups for the Large Underground Waste Storage Tanks at the Hanford Site, Rev. 8, Washington River Protection Solutions, LLC, Richland, Washington.

SD-WM-TC-005, 1994, Test Procedure for Use of the Shear Vane in Tanks 103-SY, 103-AN, and 103- $A W$, Rev. 0, Westinghouse Hanford Company, Richland, Washington.

Stewart, D. P. and M. F. Randolph, 1994, “T-Bar Penetration Testing in Soft Clay," Journal of Geotechnical Engineering, Vol. 120, No. 12, pp. 2230-2235. 
van Kessel, T. and W. G. M. van Kesteren, 2002, "Gas Production and Transport in Artificial Sludge Depots," Waste Management, Vol. 22, pp. 19-28.

Wesley, L. D., 2002, "Interpretation of Calibration Chamber Tests Involving Cone Penetrometers in Sands," Géotechnique, Vol. 52, No. 4, pp. 289-293.

WHC-SD-WM-SDD-063, 1996, System Design Description Cone Penetrometer System, Rev. 0, Westinghouse Hanford Company, Richland, Washington. 